\title{
PATTERN AND CLINICAL PRESENTATION OF STDS AMONG HIV POSITIVE AND NEGATIVE INDIVIDUALS AT A RURAL REFERRAL CENTRE
}

Rajesh Rajagopalan

\section{Associate Professor. Department of Skin \& STDs, IRT Perundurai Medical College, Perundurai, Erode}

\section{CORRESPONDING AUTHOR:}

Dr. Rajesh Rajagopalan

Associate Professor, Department of Skin \& STDs, IRT,

Perundurai Medical College,

Perundurai, Erode District. PIN Code- 638053.

E-mail: rajrajskin@yahoo.co.in

INTRODUCTION: Globally the majority of human immunodeficiency virus (HIV) epidemic is through heterosexual transmission; The complex interaction between STD and the HIV has been demonstrated in many epidemiological, in vitro and clinical studies over the last number of years. Classic STD could facilitate HIV 1 transmission by increasing either the infectiousness of the index case, the susceptibility of the partner, or both.

\section{AIMS AND OBJECTIVES: The present study was undertaken to assess the following}

- A) Prevalence of STDs

- B) Comparison among HIV positive and negative individuals.

MATERIALS AND METHODS: It was a descriptive study in which all patients who attended the Dermatology and Venereology outpatient department were screened for STDs infection. The study was conducted in the month of May to June 2007 at IRT- Perundurai Medical College hospital, Perundurai. Detailed history including age , sex, socio economic status, occupation, marital status, sexual history, history of presenting illness, past history (previous STDs, smoking, ganja addict, alcohol, IVDU) were elicited. Patients were subjected to thorough clinical examination.

The clinical diagnosis of STDs was supplemented with necessary laboratory procedures as and when required. In the study, subject sera were collected after informed written consent. Ethical committee clearance was obtained to conduct this study. All the serum samples are tested for HBsAg and anti-HCV antibodies by immuno chromatographic (rapid test) assay. These patients were also tested for RPR(serological test for syphilis) and ELISA for HIV(after pre test counseling) at Integrated Counseling and Testing Centre (ICTC). Testing for syphilis done by RAPID PLASMA REAGIN card using kits of CARBOGEN [Tulip diagnostics (p) LTD, Goa ]

\section{RESULTS:}

1. Total number of the patients who attended the Skin and STDs OP from May to June 2007

2. Total number of the patients with $\mathrm{H} / 0$ exposure

3. Total number of the patients enrolled in the study after informed written consent

$$
=130
$$


4. Total number of the patients screened for serology of HBV/HCV/ SYPHILIS/HIV

Results were tabulated as follows

\section{Sex distribution}

Table no: 5.1 sex distribution in the study group $(n=130)$

Majority of the study subjects were males $(n=102)$. Rest of the study group were females $(n=28)$.

\section{Age group distribution}

Table no: 5.2 age group distribution of the study group $(n=130)$

\begin{tabular}{|c|c|c|}
\hline Age group in years & Total NO. & Percentage (\%) \\
\hline 15-19 & 5 & 3.85 \\
\hline $20-24$ & 11 & 8.46 \\
\hline $25-29$ & 17 & 13.07 \\
\hline $30-34$ & 25 & 19.23 \\
\hline $35-39$ & 32 & 24.62 \\
\hline $40-44$ & 18 & 13.85 \\
\hline $45-49$ & 12 & 9.23 \\
\hline $50-54$ & 4 & 3.08 \\
\hline $55-59$ & 3 & 2.31 \\
\hline Sex & Total No & Percentage (\%) \\
\hline Male & 102 & 78.5 \\
\hline Female & 28 & 21.5 \\
\hline $60-64$ & 2 & 1.54 \\
\hline 65-69 & 1 & 0.77 \\
\hline
\end{tabular}

Most of the patients in the study group belonged to the age group of 35-39 years $(n=32)$ followed by 30-34 years $(n=25)$. The youngest and the oldest patient encountered in the study was aged 18 and 66 respectively.

\section{OCCUPATION TABLE NO: 5.30CCUPATION OF THE PATIENTS IN THE STUDY GROUP} $(n=130)$

\begin{tabular}{|l|l|l|}
\hline Occupation & Total No. & Percentage(\%) \\
\hline Driver/Transport worker & 31 & 23.85 \\
\hline Daily wage laborers & 25 & 19.23 \\
\hline Skilled/ semi skilled workers & 22 & 16.92 \\
\hline Weaver & 15 & 11.54 \\
\hline Home maker & 13 & 10.00 \\
\hline Farmer & 7 & 5.38 \\
\hline Student & 5 & 3.85 \\
\hline Tailor & 5 & 3.85 \\
\hline Salesman & 3 & 2.31 \\
\hline Painter & 2 & 1.51 \\
\hline Business men & 1 & 0.77 \\
\hline Unemployed & 1 & 0.77 \\
\hline Hotel worker & 1 & 0.77 \\
\hline
\end{tabular}


Commonest occupation of the group was Drivers/Transport $(n=31)$ followed by daily wage laborers skilled / semi skilled workers, weavers etc.,

\section{Socio economic status}

Table no: 5.4 socio economic status of the patients in the study group $(n=130)$

\begin{tabular}{|l|l|l|}
\hline Socio economic status & Total No. & Percentage (\%) \\
\hline High & 1 & 0.77 \\
\hline Moderate & 20 & 15.38 \\
\hline low & 109 & 83.85 \\
\hline
\end{tabular}

Majority of our patients belonged to low socio economic status $n=109$ ) followed by moderate and high socio economic status.

\section{Marital status}

Table no: 5.5 marital status of the patients in the study Group $(n=130)$

\begin{tabular}{|l|l|l|}
\hline Marital status & Total No. & Percentage(\%) \\
\hline Married & 91 & 70 \\
\hline Unmarried & 39 & 30 \\
\hline
\end{tabular}

\begin{tabular}{|l|l|l|l|l|}
\hline & \multicolumn{2}{|l|}{ HIV } & \multicolumn{2}{l|}{ NON HIV } \\
\hline Marital status & Male & Female & Male & Female \\
\hline Married & 50 & 21 & 16 & 4 \\
\hline unmarried & 18 & 1 & 18 & 2 \\
\hline
\end{tabular}

Majority of the patients in the study group were married $(n=91)$. Among the married $(n=91)$ there were 5 widows (HIV positive women who lost their husband due to AIDS ) and 2 remained single [divorcees (1 HIV,1 Non HIV)].

Among the women , 25 were housewives. Among the unmarried women in the study group ( $\mathrm{n}=3), 2$ were CSWS/ 1 deserted.

\section{Sexual History}

Table no: 5.6 sexual history of the patients in the study group $(n=130)$

\begin{tabular}{|l|l|l|}
\hline Contacts & Total No. & Percentage (\%) \\
\hline EMC & 90 & 69.23 \\
\hline EMC/PMC & 68 & 52.30 \\
\hline PMC & 49 & 37.69 \\
\hline
\end{tabular}

Among the unmarried patients 27 had exposure to commercial sex workers, rest of them had contact unprotected with known partner (lovers, kept mistress, co-workers). Among the married persons 49 reported pre marital contacts, 90 reported extra marital contacts and 68 having both.

Hetero sexual route was observed to be the most common mode of acquiring STDs. MSMW [bisexuality $(\mathrm{n}=6)$ ] and MSM [homosexuality $(\mathrm{n}=5)]$ were also observed in this study. 


\section{Personal history}

Table no: 5.7 personal history of the study subjects $(n=130)$

\begin{tabular}{|l|l|l|}
\hline Personal habits & Total No. & Percentage (\%) \\
\hline Alcoholism & 81 & 62.31 \\
\hline Smoking & 79 & 60.77 \\
\hline Ganja addict & 1 & 0.77 \\
\hline IVDU & 0 & 0 \\
\hline
\end{tabular}

Nearly $2 / 3^{\text {rd }}$ of the patients in the study group were found to be indulging in alcohol and smoking .They have taken alcohol regularly or irregularly. Both habits were found in $58.46 \%$ $(n=76)$ of the study subjects. Among the females, one women was having practice of alcohol intake alone and other was having both the habits of alcohol and smoking. Both were commercial sex workers. One male in the study group has ganja addiction. None of the study subjects were Intravenous Drug Addicts.

\section{Past history}

Table no: 5.8 past history of the STDs in the study group ( $n=130)$

\begin{tabular}{|l|l|l|}
\hline Past history & Total No. & Percentage (\%) \\
\hline Present & 47 & 36.15 \\
\hline Absent & 83 & 63.85 \\
\hline
\end{tabular}

47 patients in the study group reported H/O STDs in the past, 34 were males and 13 were females. Majority of them $(n=25)$ reported genital ulcerative diseases. 11 of them reported $\mathrm{H} / \mathrm{O}$ genital discharge and $5 \mathrm{H} / \mathrm{O}$ of warts.

\section{Presenting complaints}

Tablet no:5.9 complaints of the patients in the study subjects $(n=130)$

\begin{tabular}{|l|l|l|}
\hline Complaints & Total no. & Percentage (\%) \\
\hline Cough with expectoration & 32 & 24.62 \\
\hline Genital ulcer & 24 & 18.46 \\
\hline For check up & 15 & 11.54 \\
\hline Itching in genitalia & 10 & 7.69 \\
\hline Abdominal pain & 10 & 7.69 \\
\hline Diarrohea & 10 & 7.69 \\
\hline Loss of weight & 9 & 6.92 \\
\hline Genital growth & 8 & 6.15 \\
\hline Itching all over the body & 8 & 6.15 \\
\hline Genital discharge & 7 & 5.38 \\
\hline Dysuria & 7 & 5.38 \\
\hline Fever & 7 & 5.38 \\
\hline Burning micturition & 6 & 4.61 \\
\hline Itching in groin & 6 & 4.61 \\
\hline Headache & 6 & 4.61 \\
\hline Swelling in the neck & 6 & 4.61 \\
\hline
\end{tabular}


CASE STUDIES

\begin{tabular}{|l|l|l|}
\hline Loss of appetite & 5 & 3.85 \\
\hline Weakness of face & 3 & 2.31 \\
\hline Genital pain & 3 & 2.31 \\
\hline Pain during swallowing & 2 & 1.54 \\
\hline Mouth ulcers & 2 & 1.54 \\
\hline Discoloration of genitalia & 1 & 0.77 \\
\hline Unable to retract the prepuce & 1 & 0.77 \\
\hline Skin rash & 1 & 0.77 \\
\hline Abdomen distension & 1 & 0.77 \\
\hline Fits & 1 & 0.77 \\
\hline
\end{tabular}

The most common complaint observed in the study group was cough with expectoration $(n=32)$. The most common symptom pertaining to STDs. noticed was genital ulcer, followed by growth, discharge, dysuria and burning micturition. A noticeable number of patients $(n=15)$ has no symptoms. The other common symptoms were generalized and localized itching, diarrhea, fever, abdominal pain etc.,

\section{Pattern of STIs in the study group}

Table no.5.10 pattern of STIs in the study group table $(n=130)$

\begin{tabular}{|l|l|l|l|l|}
\hline Disease & Total no & Male & Female & Percentage(\%) \\
\hline Genital herpes & 37 & 31 & 6 & 28.46 \\
\hline Genital candidiasis & 14 & 8 & 6 & 10.76 \\
\hline Genital warts & 11 & 8 & 3 & 8.46 \\
\hline Scabies & 10 & 10 & 0 & 7.69 \\
\hline Tinea cruris & 9 & 9 & 0 & 6.92 \\
\hline Non specific urethritis & 7 & 6 & 1 & 5.38 \\
\hline Syphilis & 6 & 4 & 2 & 4.61 \\
\hline Molluscum contagiosum & 5 & 4 & 1 & 3.85 \\
\hline Trichomonas Vulvo Vaginalis & 5 & 0 & 5 & 3.85 \\
\hline Hepatitis - B & 5 & 5 & 0 & 3.85 \\
\hline Non candidal balanitis & 4 & 4 & 0 & 3.08 \\
\hline Chancroid & 3 & 2 & 1 & 2.31 \\
\hline Non Specific genital ulcer & 3 & 2 & 1 & 2.31 \\
\hline Non gonococcal urethritis & 3 & 2 & 1 & 2.31 \\
\hline Bacterial vaginosis & 3 & 0 & 3 & 2.31 \\
\hline Pediculosis pubis & 2 & 2 & 0 & 1.54 \\
\hline Hepatitis - C & 1 & 1 & 0 & 0.77 \\
\hline Gonorrhea & 1 & 1 & 0 & 0.77 \\
\hline
\end{tabular}

Among the study subjects $(n=130)$, eight were found to be free of any venereal diseases $(7$ males, 1 female). 
11. Results of investigations in the study group

Table no: 5.11 - a rapid plasma reagin (rpr) reactivity $(n=105)$

\begin{tabular}{|c|c|c|}
\hline Serological test for syphilis - RPR & Total No. & Percentage (\%) \\
\hline Reactive & 6 & 4.61 \\
\hline Non -reactive & 124 & 95.39 \\
\hline
\end{tabular}

Among the study subjects $(\mathrm{n}=130)$, RPR was found to be reactive in $6(4.61 \%)$ cases and non reactive in 124 (95.39\%) patients.

Table no: 5.11 - b prevalence of hiv infections $(n=105)$

\begin{tabular}{|l|l|l|}
\hline ELISA for HIV antibodies & Total No. & Percentage (\%) \\
\hline Positive & 90 & 69.23 \\
\hline Negative & 40 & 30.77 \\
\hline
\end{tabular}

Among the study subjects screened for HIV antibodies ( $n=130)$, HIV (ELISA) was found to be positive in $90(69.23 \%)$ cases. 40 patients (30.77\%) had no HIV antibodies in their serum by ELISA test.

Table no: 5.11-c prevalence of anti-HCV antibodies $(n=130)$

\begin{tabular}{|l|l|l|}
\hline Anti-HCV antibodies & Total No. & Percentage(\%) \\
\hline Positive & 1 & 0.77 \\
\hline Negative & 129 & 99.23 \\
\hline
\end{tabular}

Among the study subjects $(\mathrm{n}=130)$, anti-HCV antibodies were detected in 1 case.129 patients (99.23\%) had no anti-HCV antibodies in their serum by ICR assay.

Table no: 5.11-d prevalence of HBs ag $(n=130)$

\begin{tabular}{|l|l|l|}
\hline HBs Ag (ICR) & Total No. & Percentage(\%) \\
\hline Positive & 5 & 3.85 \\
\hline Negative & 125 & 96.15 \\
\hline
\end{tabular}

Among the study subjects $(n=130)$, HBs Ag was present in $5(3.85 \%)$ cases and it was negative in $125(96.15 \%)$ patients .

Table no: 5.11-e organisms isolated in urine culture among the study group with symptoms

\begin{tabular}{|l|l|}
\hline Organisms & Total No. \\
\hline N. gonorrhea & 1 \\
\hline Escherichia coli & 1 \\
\hline Klebsiella spp. & 1 \\
\hline Staphylococcus aureus & 1 \\
\hline
\end{tabular}

No organisms were isolated in 7 cases (5.38\%). They were labeled as non specific urethritis. 12. Distribution of infections among hiv positive individuals in the study group 
Table no: 5.12 distribution of infections among hiv positive individuals in the study group $(n=90)$

\begin{tabular}{|l|l|l|}
\hline Infections & Total no. & Percentage (\%) \\
\hline Genital herpes & 30 & 33.33 \\
\hline Genital candidiasis & 10 & 11.11 \\
\hline Genital warts & 7 & 7.77 \\
\hline Tinea cruris & 5 & 5.55 \\
\hline Molluscum contagiosum & 4 & 4.44 \\
\hline Trichomonas Vulvo Vaginalis & 4 & 4.44 \\
\hline Hepatitis - B & 4 & 4.44 \\
\hline Scabies & 2 & 2.22 \\
\hline Non specific urethritis & 2 & 2.22 \\
\hline Syphilis & 2 & 2.22 \\
\hline Chancroid & 2 & 2.22 \\
\hline Non Specific genital ulcer & 2 & 2.22 \\
\hline Non gonococcal urethritis & 1 & 1.11 \\
\hline Bacterial Vaginosis & 1 & 1.11 \\
\hline Pediculosis pubis & 1 & 1.11 \\
\hline Hepatitis - C & 1 & 1.11 \\
\hline
\end{tabular}

13. Comparison of infections in $\operatorname{hiv}(n=90)$ and non hiv(n=40) patients

Table no: 5.13

\begin{tabular}{|l|l|l|l|l|}
\hline Infection & HIV & Percentage (\%) & Non-HIV & Percentage (\%) \\
\hline Genital herpes & 30 & 33.33 & 7 & 17.5 \\
\hline Genital candidiasis & 10 & 11.11 & 4 & 10 \\
\hline Genital Warts & 7 & 7.77 & 4 & 10 \\
\hline Tinea cruris & 5 & 5.55 & 4 & 10 \\
\hline Non candidal balanitis & 0 & 0 & 4 & 10 \\
\hline Hepatitis B & 4 & 4.44 & 1 & 2.5 \\
\hline $\begin{array}{l}\text { Molluscum } \\
\text { contagiosum }\end{array}$ & 4 & 4.44 & 1 & 2.5 \\
\hline Trichomoniasis & & & & \\
\hline Scabies & 4 & 4.44 & 1 & 2.5 \\
\hline Non specific urethritis & 2 & 2.22 & 8 & 20 \\
\hline Syphilis & 2 & 2.22 & 5 & 12.5 \\
\hline Chancroid & 2 & 2.22 & 4 & 10 \\
\hline Non Specific genital ulcer & 2 & 2.22 & 1 & 2.5 \\
\hline Non gonococcal urethritis & 1 & 2.22 & 1 & 2.5 \\
\hline Bacterial Vaginosis & 1 & 1.11 & 2 & 5 \\
\hline Hepatitis - C & 4 & 4.44 & 2 & 5 \\
\hline Gonorrhea & 0 & 0 & 1 & 2.5 \\
\hline
\end{tabular}


14. concomitant infections in hiv patients $(n=90)$

table no: 5.14

\begin{tabular}{|l|l|l|}
\hline CONCOMITANT INFECTION & TOTAL NO & PERCENTAGE (\%) \\
\hline HIV + Genital Herpes & 30 & 33.33 \\
\hline HIV + Genital Candidiasis & 10 & 11.11 \\
\hline HIV + Genital warts & 7 & 7.77 \\
\hline HIV + Molluscum contagiosum & 4 & 4.44 \\
\hline HIV + Trichomoniasis & 4 & 4.44 \\
\hline HIV + Hepatitis B & 4 & 4.44 \\
\hline HIV + Scabies & 2 & 2.22 \\
\hline HV + Non specific urethritis & 2 & 2.22 \\
\hline HIV + Syphilis & 2 & 2.22 \\
\hline HIV + Chancroid & 2 & 2.22 \\
\hline HIV + Non Specific genital ulcer & 2 & 2.22 \\
\hline HIV + Non gonococcal urethritis & 1 & 1.11 \\
\hline HIV + Bacterial vaginosis & 1 & 1.11 \\
\hline HIV + Pediculosis pubis & 1 & 1.11 \\
\hline HIV + Hepatitis - C & 1 & 1.11 \\
\hline
\end{tabular}

\section{Concomitant infections in the non-hiv individuals $(n=40)$}

Table no: 5.15

\begin{tabular}{|l|l|l|}
\hline concomitant infection & total no & percentage (\%) \\
\hline Balanoposthositis + chancroid & 1 & 2.5 \\
\hline Balanoposthositis + scabies & 1 & 2.5 \\
\hline Chancroid + Scabies & 1 & 2.5 \\
\hline Candidal balanitis + genital warts & 1 & 2.5 \\
\hline Genital herpes + Non specific urethritis & & \\
\hline Pelvic inflammatory disease + Non specific urethritis & 1 & 2.5 \\
\hline
\end{tabular}

DISCUSSION: In the study, 102 were males, 28 were females.

Majority of the patients were in the age group of 35-39 followed by 30-34 (mean age $=37$ ) and that of female $18-47$ years (mean age $=33$ years). The mean age of the entire study population was 35 years.

Most of patients in the study are at an unusually high risk of contracting STI due to migrating of the profession.

Majority of the patients belonged to lower socio economic state, representing rural area. Significant low educational status seen in our study could be the reason for unawareness of 
mode of transmission and preventive measures for STDs. Majority of the patients in their study group were married. One - third of patients in the study were unmarried. The latter group forms an important risk group for acquiring STDs including HIV infection as they are exposed to high risk sexual behavior.

Heterosexuality was the predominant sexual behaviour followed by bisexuality and homosexuality. In the present study, the incidence of bisexual orientation was higher compared to those who were only homosexuals. Which is a cause of concern as more often these bisexual males are married and they carry an increased risk of transmitting infection to their spouse. (High risk sexual behaviours but low risk perception). History of promiscuity was elicited in all males in the study. Among them , majority gave the history of exposure to female commercial sexual worker. Friends, relatives and co-workers were the next possible source of infection. The usage of condoms among them was either irregular or absent.

Majority of the married women $(n=25)$ denied history of pre marital or extra marital contacts. Most of the married women blamed their husband for the source of infection. This stresses the fact that innocent housewives were infected by their promiscuous husbands.

Two women (female CSWS) gave H/O exposure with multiple males. None of them were found to be practice safe sex. Two-thirds of the individuals did not use condoms despite half of them knowing their protective action..

Genital ulcer was the most commonest previous STDs noted. Genital infections particularly ulcerative diseases are associated with increased sexual transmission of HIV.

Majority of the patients in the study group were found to be practicing smoking or alcoholism or both. Alcoholism can act as an independent risk factor in the development of STI. 15 patients reported only for check up. But they were also found to have one or more infections. Hence it is important to screen and treat such asymptomatic cases to prevent sequences.

A good number of patients presented with various genitourinary symptoms on their own and few of them with their partner(s). This increase in number of self referral by these patients could be as a result of campaigns conducted for generating awareness.

Genital herpes was the most common STIs [( $\mathrm{n}=37), 33.3 \%)]$ similar study in India by Ambhore et al ${ }^{110}$ noted. Among the viral STDs, genital warts $(n=11)$ was the next commonest, followed equally by Molluscum contagiosum $(n=5)$ and Hepatitis B $(n=5)$. Antibodies to HCV was seen only in 1 patient.

Among the bacterial STDs observed in the study group, Non specific urethritis ( $n=7)$ was the commonest, followed by syphilis $(n=6)$, balanitis $(n=4)$, chancroid $(n=3)$, non specific genital ulcer $(n=3)$, non gonococcal urethritis $(n=3)$, bacterial vaginosis $(n=3)$ and gonococcal urethritis $(\mathrm{n}=1)$. Giant (extra genital) lesions due to breaking down of inflammatory chancroid was noted in 2 cases ( HIV positive 1 male, HIV Negative 1 female). The third HIV positive male case with chancroid showed poor response to antibiotics (possibility of mixed infections). Hence to detect co-infections special techniques like multiplex PCR should be employed. E. Coli, Klebsiella, staphylococcus were the microbes isolated in urine culture \& sensitivity showing multi drug resistance in the study population. Non specific urethritis \& Non gonococcal urethritis were seen more in males than females. Poor genital hygiene was noted among them.

Among the parasitic infections in the study populations, Scabies was the commonest $(n=10)$, followed by Trichomoniasis $(n=\%)$ and Pediculosis pubis $(n=2)$. Itching, the classical symptom was not found in HIV cases with scabies. We have not encountered Norwegian type.

Genital candidiasis was the commonest fungal infection $(n=14)$ followed by dermatophytosis of the groin $(n=9)$. 
The prevalence of RPR reactivity was $4.61 \%(n=6)$. Latent syphilis $(n=3)$, malignant annular syphilide $(n=2)$ and early syphilis $(n=1)$ were the stages of luetic disease seen in this study. The types of secondary syphilis noted were annular (usually noticed in late secondary times) and malignant pustular syphilides (more commonly reported in HIV in recent times). The prevalence rate of syphilis in the developing countries is between 319109. No serological abnormalities were observed in this study. The classical STDs like lymphogranuloma venereum and granuloma inguinale were not observed.

In our study, we have found HBs Ag in $3.85 \%(n=5)$ which is on par or lower with Indian studies ${ }^{110}$. Hence routine screening of all the STD attendees for HBs Ag is recommended.

Of the total 130 sera tested, anti-HCV antibodies were detected in one patient $(0.77 \%)$. The other sera $(n=129)$ were negative for anti HCV antibodies. Antibodies to HCV were present in $0.64 \%$ of STD patients in a study by Tungatkar et al ${ }^{110}$. at national institute of virology, Pune, which is on par with our study. From North India , a sero prevalence of $0.8 \%$ has been reported from STD patients ${ }^{107}$. 4 out of $5 \mathrm{HBV}$ infected individuals were found to be co-infected with HIV. The person with antibodies to HCV was also found to be HIV positive.

HBV with HCV coexistence as reported in other studies is not found in this study. In our study, all isolated cases with HBV/HCV infection were found to be males. Therefore, it is suggested that screening for all HBs Ag positive cases should be done for HCV infection also, so that coinfection should be treated to reduce morbidity and mortality.

In the study group the prevalence of HIV was $69.23 \%(n=90)$ which is relatively higher than other Indian studies. This could be due to referral of cases to our tertiary care centre which is equipped with multi disciplinary team.

Among the HIV positive patients in this study group, viral STDs [genital herpes $(\mathrm{n}=30) /$ warts (n=7) / Hepatitis-B (n=4) / Molluscum contagiosum ( $n=4) /$ Hepatitis-C $(n=1)]$ were found to be more common than bacterial STDs. In the recent times, genital warts have been observed as the newly emerging viral STDs after genital herpes. Most of the STIs presented with classical presentations, course and therapeutic response to the conventional treatment.

Atypical forms (chronicity / extensive anogenital / recurrent / non healing / slow healing / granulomatous / with severe secondary infection / mixed venereal infection) of HSV-II were observed in this study.

Molluscum contagiosum (numerous lesions / extragenital), warts (extensive / with secondary infection / ulceration / hemorrhage / recalcitrant to treatment ) were found among HIV subjects in this study group.

Non specific urethritis [2 (HIV) vs. 5(non HIV)], Syphilis [2(HIV) vs. 4 (non HIV) ] , Scabies [2(HIV) vs. 8(non HIV)], Bacterial vaginosis [1(HIV) vs. 2 (non HIV) ] were found in non HIV subjects more than HIV .

Prevalence of genital candidiasis [Balanitis in males and vulvovaginitis in females] was equal in both [HIV(11.11\%) / non HIV( 10\%)] study groups. Prevalence of other STDs like chancroid, non specific genital ulcer, pediculosis pubis were almost equal in both groups. Gonococcal urethritis was found in a non HIV, unmarried male. Balanitis (bacterial )/ Gonococcal urethritis were found only in non HIV study subjects. Patients with STDs in HIV were found to be more symptomatic leading to late diagnosis and more duration of therapy with costly drugs. However we did not encounter any genital malignancy.

Co-infections (mixed infections) with two or more organisms occurred in significant percentage of study group. 
CONCLUSION: The present study concludes that there was a high prevalence of STDs in both HIV and NON HIV study population. The sexually promiscuous persons (SPPs) and the STD clinic attendees act as high risk groups as well as bridge population in transmitting the infection to general population.

Among HIV subjects, lack of knowledge, unwillingness to use barrier due to the myths \& misconceptions, and their continual inappropriate high risk sexual behaviour predispose them to acquire and transmit STDs

Co-infections and viral STDs (herpes, warts, molluscum contagiosum HBV\& HCV) were found common among HIV patients in the study population. Bacterial STDs like syphilis, chancroid and gonorrhea were showing low prevalence in this study. This could be multifactorial (decline in STD patients in OPD / Syndromic management / awareness about condoms / wide spread use of antibacterials / modified presentation due to partial treatment). There is no significant difference of STDs among married and unmarried individuals. Atypical clinical presentation / Persistent / recurrent STDs / mixed venereal diseases / poorly responding / non responding STDs were seen among HIV subjects. There is a changing pattern of STIs from bacterial to viral in both HIV and non HIV subjects with exposure.

Barrier precautions along with behaviour interventions seems to be prudent approach in preventing STIs among high risk groups attending STD clinic.

\section{BIBLIOGRAPHY:}

1. Cohen MS.Sexually transmitted diseases enhance HIV transmission: a hypothesis no longer. Lancet 1998; 351 (Suppl III): 5-7.

2. Wasserheit JN. Epidemiological synergy : interrelationship between human immunodeficiency virus infection and other sexually transmitted disease. Sex Transm Dis 1992; 19:61-77.

3. Fleming DT, Wasserheit JN. From epidemiological synergy to public health policy and practice: the contribution of other sexually transmitted diseased to sexual transmission of HIV infection. Sex Transm Inf 1999;75:3-17.

4. Kar H K, Jain R.k. Sharma PK, et al. Increasing HIV prevalence in STD clinic attendees in Delhi, India:6 year (1995-2000) hospital based study results. Sex Transm Inf 2001; 77: 393.

5. Kumar B, Gupta S. Rising HIV prevalence in STD clinic attendees at Chandigarh (North India) - A relatively low prevalence area. Sex Transm Inf 2000;7fsaq6:56.

6. Moss GB, Kreiss JK. The interrelation between human immunodeficiency virus infection and other sexually transmitted diseases (Review). Med Clin North Am 1990;74:16471660.

7. Laga M, Nzila N, Goeman J. The interrelationship of sexually transmitted diseases and HIV infection; implications for the control of both epidemics in Africa (Review). AIDS 1991; 5-S55-53.

8. Wasserheit JN. Epidemiological synergy: interrelationship between human immunodeficiency virus infection and other sexually transmitted diseases (Review). Sex Transm Dis 1992; 19; 61-77.

9. Mostad SB, Kreiss JK. Shedding of HIV 1 in the genital tract (Editorial review). AIDS 1996; 10;1305-1315. 
10. Vernazza PL. Eron JJ. Fiscus SA, Cohen MS. Sexual transmission of HIV: infectiousness and prevention. AIDS 1999; 13: 155-166.

11. Magro CM, Crowson AN, Alfa M, et al. A morphological study of penile chancroid lesions in human immunodeficiency virus (HIV) - positive and - negative African men with a hypothesis concerning the role of chancroid of in HIV transmission. Human Pathol 1996; 27: 1066-107.

12. Plummer FA, Wainberg MA, Plourde P, et al. Detection of human immunodeficiency virus type 1 (HIV 1) in genital ulcer exudates of HIV 1 - infected men by culture and gene amplification (letter). Infect Dis 1990; 161: 810-811.

13. Ghys PD, Fransen K, Diallo MO, et al. The associations between cervicovaginal HIV shedding, sexually transmitted diseases and immunosuppression in female sex workers in Abidjan, Cote d' Ivoire. AIDS 1997; 11: F85 - 93.

14. Theus SA, Harrich DA, Gaynor R, Radolf D, Norgard MV. Treponema Pallidum lipoproteins and synthetic lipoprotein analogues induce human immunodeficiency virus type 1 gene expression in monocytes via NF - Kb Activation. J Infect Dis 1998; 177:941950.

15. Kreiss J.Willerford DM, Hensel M. et al. Association between cervical inflammation and cervical shedding of human immunodeficiency virus DNA. J infect Dis 1994:170:1597 1601.

16. Ho JL, He S, Hu A, et al, Neutrophils from human immunodeficiency virus (HIV) seronegative donors induce HIV replication from HIV - infected patients mononuclear cells and cell lines: and in vitro model of HIV transmission facilitated by Chlamydia trachomatis. J Exp Med 1997 ; 181: 1403 - 1505.

17. Klebanoff SJ, Coomb RW. Virucidal effects of lactobacillus acidophilus on human immunodeficiency virus type - 1: possible role in heterosexual transmission. J Exp Med 1991; 174; 289 - 292.

18. Cohen CR, Duer RA, Pruithithada N, et al, Bacterial vaginosis and HIV seroprevalence among female commercial sex workers in Chaing Mai. Thailand. AIDS.

19. Schmid G, Markowitz L, Joesoef R, Koumans E. Bacterial vaginosis and HIV infection. Sex Transm Inf 2000; 76; 3-4.

20. Korenromp EL, Sake J, Vlas DE, et al. Estimating the magnitude of STD cofactor effects on HIV transmission. How well can it be done? Sex Transm Dis 2001; 28: 613-621.

21. Tramont EC. Syphilis in AIDS era. N Engl J Med 187; 316: 1600-1601.

22. Olansky S. Late benign syphilis (Gumma). Med Clin North Am 1964; 48: 653-665.

23. Potehayer N. et al. International Conference of AIDS $1: 263$ (Abstract number PB 0482 ) 1994; 7 -12.

24. Catherine $\mathrm{N}$, et al. Altered clinical presentation of early syphilis patients with HIV infections. Ann Intern Med 1994; 121: 94-99.

25. Caumes E, et al. Altered clinical presentation early syphilis patients with HIV infections. Ann Intern Med 1994; 121: 94-99.

26. Renee AG. et al. An unusual presentation of secondary syphilis in patients with HIV infection. Arch Dematol 1992; 128 : 158 - 534.

27. Schofer $\mathrm{H}$, et al. Active syphilis in HIV infection: a multicetric retrospective survey. Genitourin Med 1996; 72: 176-181.

28. Joyce PW, et al. Syphilitic retinitis in a homosexual man with concurrent HIV infection: case report. Genitourin Med 1989; 65; 244-247. 
29. Olmos JM, et al, Superior vena cava syndrome secondary to syphilitic aneurysm of the ascending aorta in a human immunodeficiency virus infected patients. Clin Infect Dis 1998; 27; 1331: 1332.

30. Hay PE, et al, Superior vena cava syndrome secondary to syphilitic aneurysm of the ascending aorta in a human immunodeficiency virus infected patients. Clin Infect Dis $1998 ; 27 ; 1331-1332$.

31. A z Behrens GM, et al. Immune reconstituting syndrome in human immunodeficiency virus infection following effective antiretroviral therapy. Immunobiol 200; 202; 186 193.

32. Jones $\mathrm{RD}$, et al, Alteration in the natural history of neurosyphilis by concurrent infection with human immuno deficiency virus. N Engl J Med 1987; 316: 1569 - 1572.

33. Daniel MM, et al. Effect of human immuno deficiency virus infection on the course of syphilis and on the response to treatment. Ann Intern Med 1990; 113; 872- 881.

34. Holtom PD, et al. Prevalence of neurosyphilis in HIV infected with latent syphilis. AM J Med 1992; 93; 9-12.

35. Katz DA, et al. Neurosyphilis - A comparative study of the effects of infection with HIV. Arch Neurol 1993; 50: 243-249.

36. Morgello S, et al. Quaternary neurosyphilis. N Engl J Med 1989; 319: 1549-1550.

37. Hay PE, et al. Detection of treponemal DNA in the CSF of patients with syphilis and HIV infection using the polymerase chain reaction. Genitourin Med 1990; 66: 428-432.

38. Van Dam J. Management of syphilis in times of HIV. Genitourin Med 1997; 13: 159-160.

39. Musher DM. Early Syphilis. In: sexually Transmitted Disease (Holmes KK, et al., Eds.). New York, McGraw - Hill, 1999; 479-486.

40. Anne MR, et al. Association of biologic false-positive reactions for syphilis with human immuno deficiency virus infection. J Infect Dis 1992; 165: 1124-1126.

41. Johnson P, et al. Specific syphilis serological tests may become negative in HIV infection. AIDS 1991; 5:419-423.

42. Johan G, et al. Similar serological response to conventional therapy for syphilis among HIV positive and HIV negative women. Genitourin Med 1995; 71: 275- 279.

43. Centers for Disease Control and Prevention. Sexually transmitted diseases treatment guidelines 2002. MMWR 2002; 51(No. RR-6): 18-25

44. Mc Grath BJ, et al. Genital herpes simplex infection in patients with the AIDS. Pharmacother 1994; 14: 529-542.

45. Cameron DW, et al. Female to male transmission of human immuno deficiency virus type 1: risk factors for seroconversion in men. Lancet 1989; 2: 403-407.

46. Hook ED, et al. Herpes simplex virus as a risk factor for human immunodeficiency virus infections in heterosexuals. J Infect Dis 1992; 165: 251-255.

47. Heng MC, et al. Co-infection and synergy of human immunodeficiency virus-1 and herpes simplex virus- 1. Lancet 1994; 343: 255-258.

48. Albrecht $\mathrm{M}$, et al. The herpes simplex virus immediate-early protein. ICP4 is required to potentiate replication of human immunodeficiency virus in CD4+ Lymphocytes. J Virol 1989; 63: 1861-1868.

49. Schacker $\mathrm{T}$, et al. Herpes virus infection in Human Immunodeficiency virus-infected persons. In: AIDS: Biology, Diagnosis, Treatment and Prevention (De Vita VT, Jr., et al., Eds.). Philadelphia, Lippincott-Raven publishers, 1997; 267-272. 
50. Augenbraun M, et al. Increased genital shedding of herpes simplex virus type 2 in HIVseropositive women. Ann Intern Med 1995; 123: 845-847.

51. Siegel FP, et al. Severe Acquired Immunodeficiency in male homosexuals, manifested by chronic perianal ulcerative Herpes Simplex lesions. N Engl J Med 1981; 305: 1439-1444.

52. Golden $\mathrm{M}$, et al. Activation of human immunodeficiency virus by herpes simplex virus. J Infect Dis 1992; 166: 494-499.

53. Ioannidis J, et al. Clinical efficacy of high dose acyclovir in patients with human immunodeficiency virus infection: a metaanalysis of randomized individual patient data. J Infect Dis 1998; 178: 349-359.

54. Adam C, et al. An overview of sexually transmitted diseases. Part III Sexually transmitted diseases in HIV-infected patients. J Am Acad Dermatol 2000; 43: 409-432.

55. Safrin S, et al. Risk factors for the development of acyclovir resistance herpes simplex virus infection. Presented at VIII International Conference on AIDS/III STD World conference, Amsterdam, 1992.

56. Bevilacqua F, et al. Acyclovir resistance/susceptibility in herpes simplex virus type 2 seqential isolates from an AIDS patient. J Acquir Immune Deficiency Syndr 1991; 4: $967-$ 969.

57. Safrin S, et al. Forscarnet resistant herpes simple virus infection in patients with AIDS. J Infect Dis 1994; 169: 193-196.

58. Nassar NN, et al. Parkland pocket guide to HIV care. 1998-99: 108.

59. King K, et al. Clinical in situ cellular response to Haemophilus ducreyi in the presence or absence of HIV infection. Int J STD AIDS 1998; 9: 537-536.

60. Pepin J, et al. The interaction of HIV infection and other sexually transmitted diseases: an opportunity for intervention. AIDS 1989; 3: 3-9.

61. Quale J, et al. Atypical presentation of chancroid in a patient infected with HIV. Am J Med 1990; 88: 43N-44N.

62. Behets FM, et al. Sexually Transmitted Diseases and HIV control in Malawi: a field study of genital ulcer disease. J Infect Dis 1995; 171; 451-455

63. Tyndall M, et al. Ceftriaxone no longer predictably cures chancroid in Kenya. J Infect Dis 1993; 167:469.

64. Jamkhedkar PP, et al. Clinicoepidemilogic features of granuloma inguinale in the era on AIDS. Sex Transm Infect 1998; 25: 196-200.

65. Maniar JK, et al. Genital ulcer diseases and HIV staus correlation in Bombay, India. Presented at the 8th International Conference on AIDS, Amsterdam 1992: abstract no. 3513.

66. Scieux C, et al. Lymphogranuloma venereum: 27 cases in Pairs. J Infect Dis 1998; 160: 662-668.

67. Matis W.L., et al. Dermatological findings associated with HIV infection. J AM Acad Dermatol 1987; 17: 746-75.

68. Yamashita $\mathrm{H}$, et al, Molecular epidemiologic analysis of Japanese patients with molluscum contagiosum. Int J Dermatol 1996; 35: 99-105.

69. Koopman RJ, et al. Mollusum contagiosum: a marker for advanced HIV infection.Br J Dermatol 1992; 126:528.

70. Ficarra G, et al. Facial and perioral molluscum contagiosum in patients with HIV infection: a report of eight cases. Oral Surg Oral Med Oral Path 1994: 78: 621-626. 
71. Brandrup F, et al, Molluscum contagiosum - induced comedo and secondary abscess formation. Pediatr Dermatol 1989; 6: 118 - 1221.

72. Fiveson DP, etal. Giant molluscum contagiosum presenting as a basal cell carcinoma in an acquired immunodeficiency syndrome patients. J AM Acad Dermatol 1988; 19; 912 914.

73. Itin $\mathrm{PH}$, et al. Molluscum contagiosum mimicking sebaceous nevus of Jadassohn, ecthyma, and giant condyloma accuminata in HIV infected patients. Dematology 1944;189: 396-398.

74. Schwartz JJ, et al. HIV related Molluscum contagiosum presenting as a cutaneous horn. Int Dermatol 1992; 31: 142-144.

75. Smith KJ, et al. Molluscum contagiosum: ultrastructural evidence for its presence in skin adjacent to clinical lesions in patents infected with HIV type 1. Arch Dermatol 1992; 128: 223-227.

76. Schwartz JJ. Molluscum contagiosum in patients with HIV infections: a review of 27 patients. J Am acad Dematol 1992; 27: 583-588.

77. Nelson MR, et al. Intralesional interferon for the treatment of recalcitrant molluscum contagiosum in HIV antibody positive individuals: a preliminary report. Int J STD AIDS 1995; 6: 351.

78. Smith K, et al. Treatment of Molluscum contagiosum virus with topical imiquimod. Presented as a poster (\#352) at the 57th Annual Meeting of the American Academy of Dermatology, New Orleans, Louisian, March 19-24, 1999.

79. Meadows KP, et al. Resolution of recalcitrant molluscum contagiosum lesion in HIV infected patients treated with cidofovir. Arch Dermatol 1997; 133: 987-990.

80. Chopra KF, et al. The impact of the HIV infection on HPV epidemic. Arch Dematol 1997; 133: 629-633.

81. Kiviat NB, et al. Association of anal dysplasia and human papilloma virus with immmunosupression and HIV infection among homosexual man. AIDS 1993; 7: 43-49.

82. Critchlow CW, et al. Association of human immunodeficiency virus and anal human papilloma virus infection among homosexual men. Arch Intern Med 1992; 152: 1673 1676.

83. Aynaud 0, et al. Comparison of clinical, histological and virological symptoms of HPV in HIV - 1 infected men and immunocompetant subjects. Sex Transm Infect 1998; 74: 3234.

84. Breese PL., et al. Anal HPV infection among homosexual \& bisexual men; prevalence of type specific infection and association with HIV. Sex Transm Dis 1995; 226: 7-14.

85. Vernon SD, et al. The HIV tat protein E2-dependent human papilloma virus 16 transcription. Virus Res 1993; 27: 133-145.

86. Holmes KK, et al. Cervical neoplasia and other STD - related genital tract neoplasias. Sexually Transmitted Diseased (Holmes KK, et al., Eds.). New York, McGraw-Hill, 1999: 811-830.

87. Centers of Disease Control and Prevention. 1993 Revised classification system for HIV function and expanded surveillance case definition for AIDS among adolescents and adults. MMWR 1992; 41: 1-19.

88. Rabkin CS, et al. Cancer incidence in a population with high prevalence of infection with human immunodeficiency virus type 1. J Natl Cancer Inst 1994; 86: 1711 - 1716. 
89. Melbye M. et al. High incidence of anal cancer among AIDS patients [Abstract PO-B141636]. X International Conference on AIDS, Berlin June 1993.

90. Weiss EG, et al. Surgery for anal lesions in HIV infected patients. Ann Med 1995; 27: 467475.

91. Kurman RJ, et al. National Cancer Institute Workshop. Interim guideline for management of abnormal cervical cytology. JAMA 1994; 271: 1866-1869.

92. Wardropperet AG, et al. Gonorrhoea as an indicator of altered sexual behavior and as surrogate maker of HIV concern: a 14 yr. analysis in Newcastel. Int J STD AIDS 1995; 6: $348-350$.

93. Rhoads JL, et al. Chronic vaginal candidiasis in women with HIV infection. JAMA 1987; 257:3105-3107.

94. Kiviat NB. Human papilloma virus and hepatitis virus in human immunodeficiency virus infected persons. In: AIDS : Biology, Diagnosis, Treatment \& Prevention (Devita VT, Jr., et al Eds.). Philadelphia, Lippincott-Raven publishers, 1997; 286-290.

95. Hall JC, et al. Norwegian scabies in a patient with acquired immunodeficiency syndrome. Cuits 1989; 43: 325-329.

96. Jucowics $P$, et al. Norwegian scabies in an infant with acquired immunodeficiency syndrome. Arch Dermatol 1989; 125: 1670-1676.

97. Currie BJ, et al. Ivermectin and crusted (Norwegian) scabies. Med J Aust 1995; 163: 559560.

98. Smith PD, et al. Intestinal infections in patients with the acquired immunodeficiency syndrome (AIDS).Ann InternMed 1988; 108: 328-333.

99. Malebranche R, et al. Acquired immunodeficiency syndrome with severe gastrointestinal manifestations in Haiti. Lancet 1985; 2: 873-878.

100. Quinn TC, et al. The polymicrobial origin of intestinal infections in homosexual men. N Engl J Med 1983; 309: 576-582.

101. Craib KJ, et al. Rectal gonorrhoea as an independent risk factor for HIV infection in a cohort of homosexual men. Genitourin Med 1995; 71: 150-154.

102. Flanigan T, et al. Cryptosporidium infection \& CD4 counts. Ann Intern Med 1992; 116: 840-842.

103. Goodgame RW. Understanding intestinal spore-forming protozoa: cryptosporidia, microsporidia, Isospora, and Cyclo-spora. Ann Intern Med 1996; 124: 429-441.

104. DeHovitz JA, et al. Clinical manifestations and therapy of Isospora belli infection in patients with the acquired immunodeficiency syndrome. New Engl J Med 1986; 315: 8790.

105. Gallant JE, et al. Incidence and natural history of cytomegalovirus disease treated with zidovudine. The Zidovudine Epidemiology Study Group. J Infect Dis 1992; 166: 12231227.

106. Sadiq ST, et al. The effect of antiretroviral therapy on HIV -1RNA loads in seminal plasma in HIV positive patients with and without urethritis. AIDS 2002; 16: 219-225.

107. Scheer $S$, et al. Effect of highly active antiretroviral therapy on diagnosis of sexually transmitted diseases in people with AIDS. Lancet 2001; 357: 432-435.

108. S. Bhattacharya, S Badrinath, A Hamide, SSujatha. Indian. J.Pathol. Microbiol 2003, vol46, No. 3: 495-497.

109. Ginna Dallabetta, Marie Laga, Peter Lampley, 1996. Control of Sexually Transmitted Diseases . AIDSCAP/Family Health International. USA :p. 169-186. 
110. S.P. Tunagatkar, A Divekar, VA Arankalle. "Exposure of STD patients and prisoners from to hepatitis B and C viruses . Indian Journal of Medical Microbiology, (1997)15(3): p. 117-119.

111. Ambhore NA, Thakar YS, Gaval SR, Joshi SG, Saoji AM. Seroprevalence of HSV-2 in STD patients with genital ulcers. Indian J Sex Transm Dis 1998; 19(2); 81-84

112. Kavin Burzin, Bilimona Fe, Rao MV. Studies on the pattern of viral STDs in era of HIV. Indian J Sex Transm Dis 2006; vol 27 No.2; 78-82.
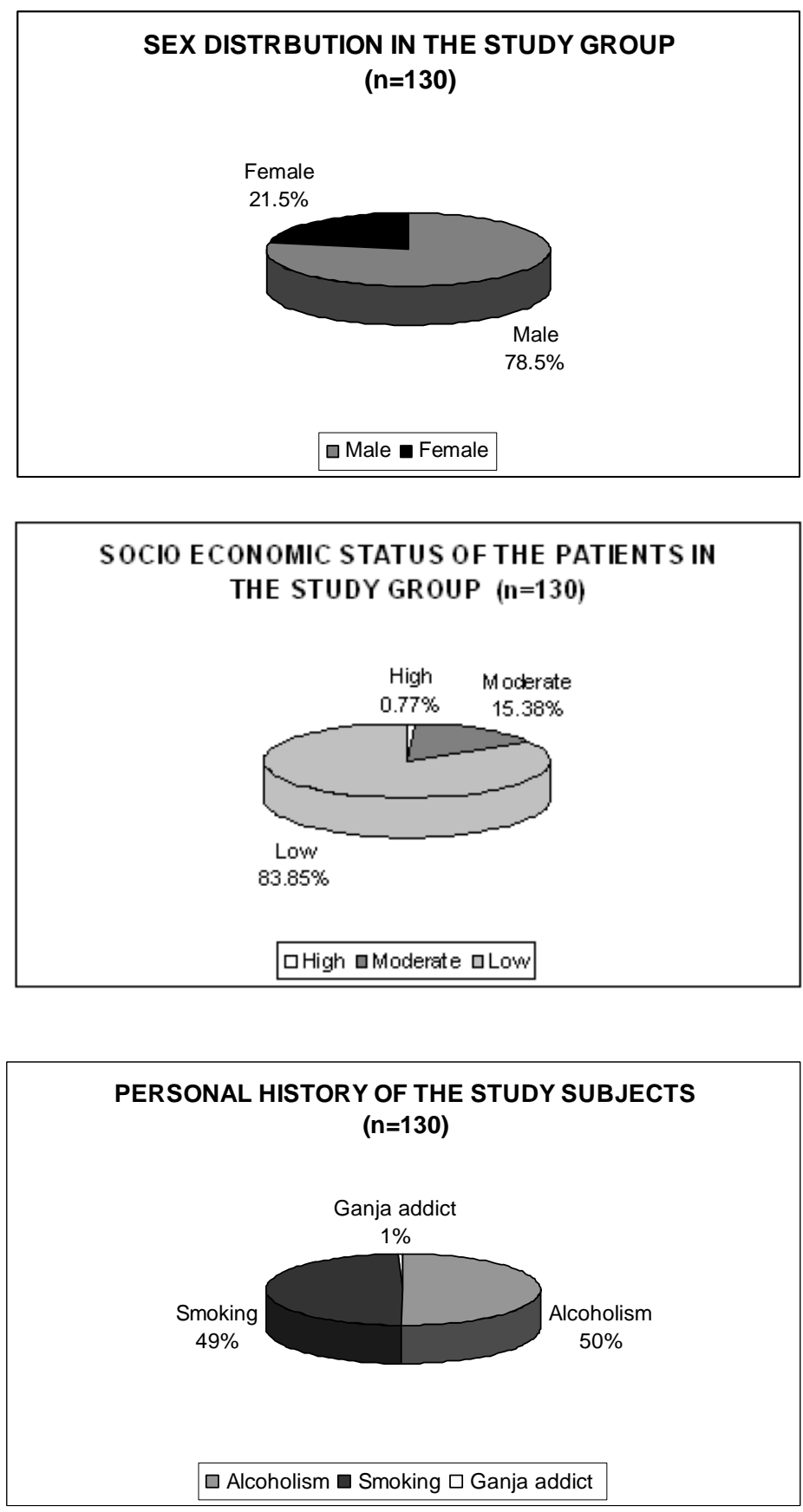
RAPID PLASMA REAGIN (RPR) REACTIVITY ( $n=105)$

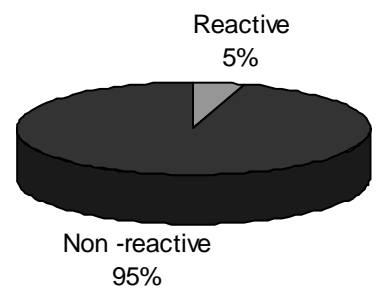

$\square$ Reactive $\square$ Non -reactive

PREVALANCE OF HIV INFECTIONS $(n=130)$

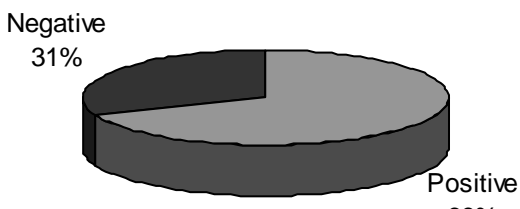

$69 \%$

$\square$ Positive $\square$ Negative

PRE VALANCE OF HBs Ag $(n=130)$

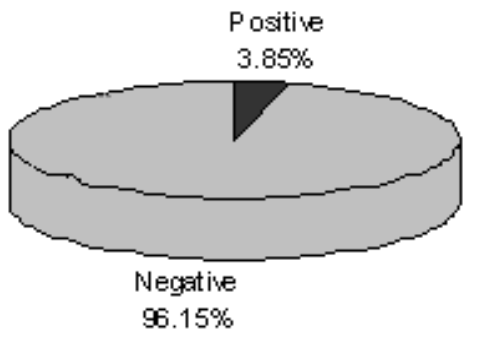

口Positive aNegative 
CASE STUDIES
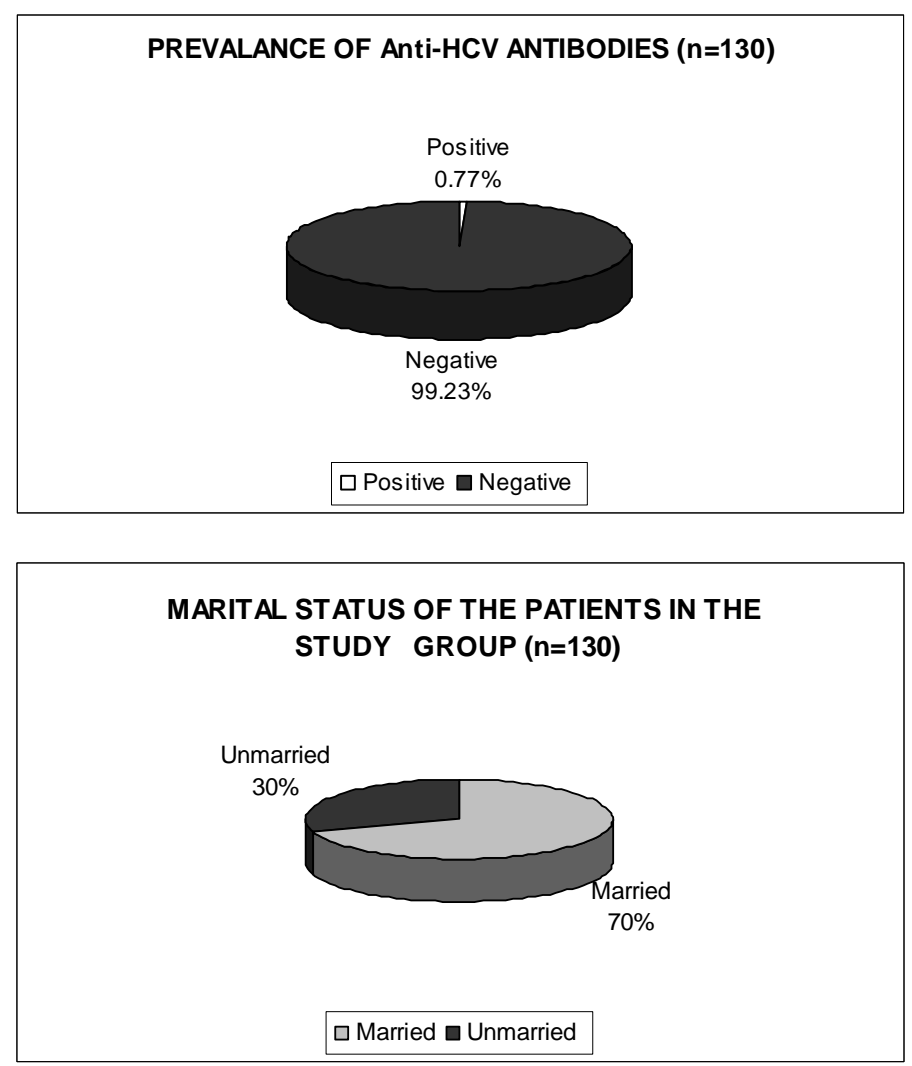

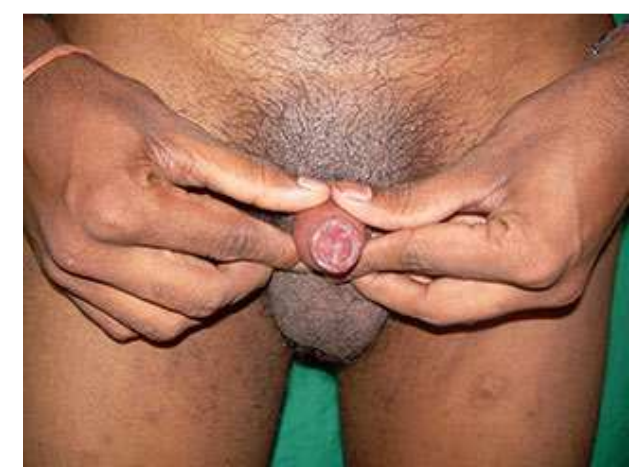

Balanoposthitis

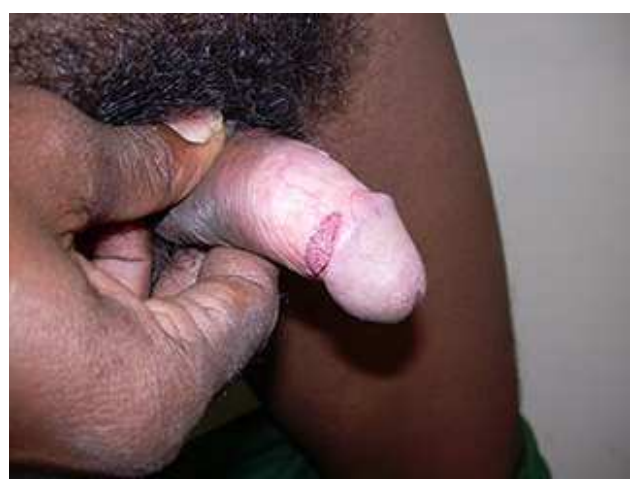

Condyloma acuminata

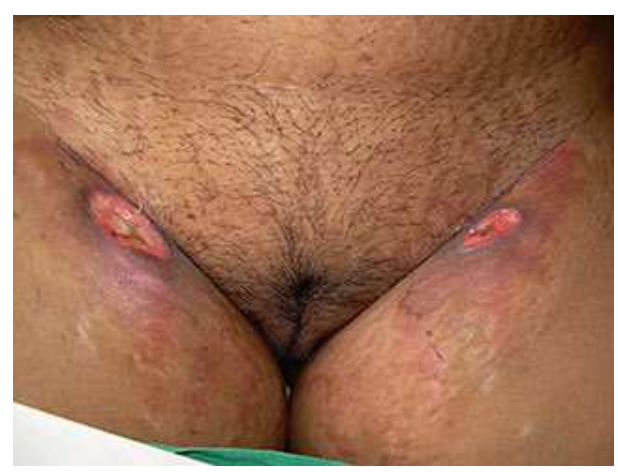

chancroid

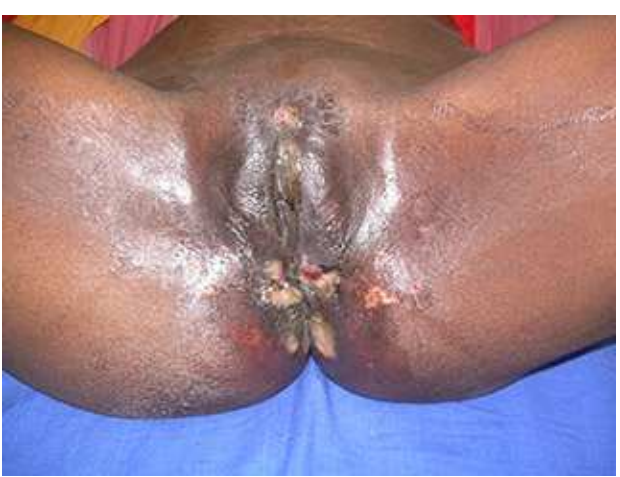

Extensive herpes with secondary infection in HIV positive fe 


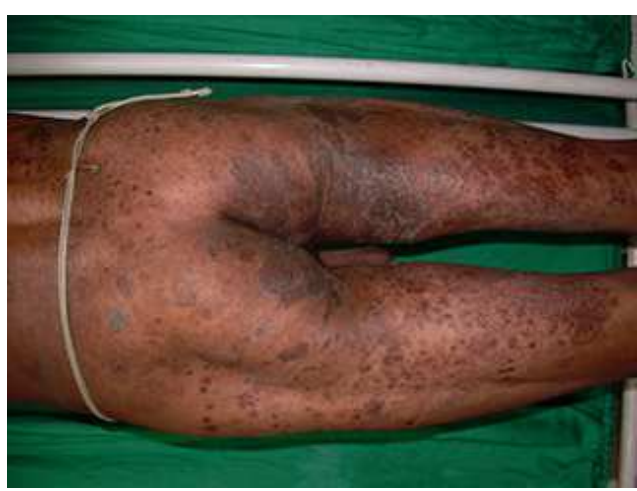

Extensive tinea with molluscum contagiosum in HIV

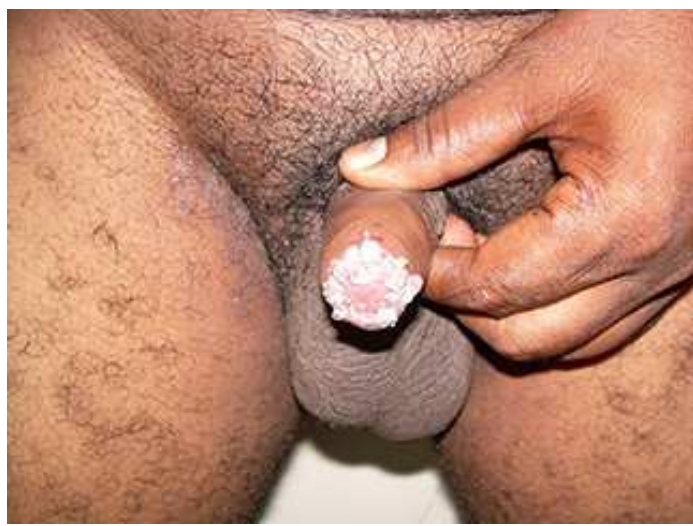

Genital warts in HIV

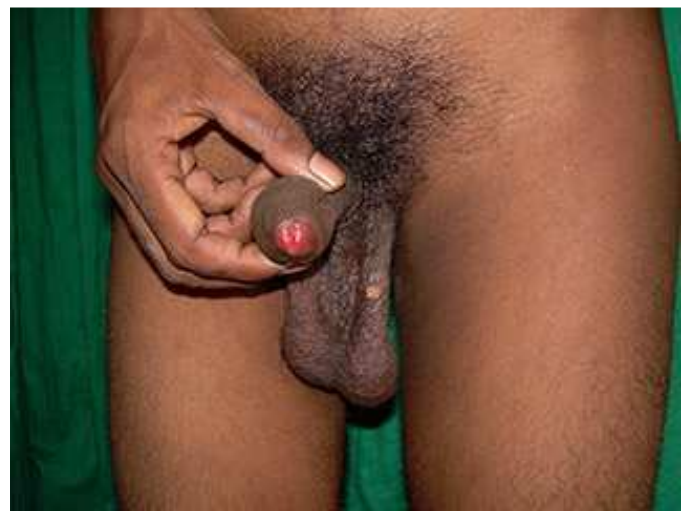

Nonspecific genital ulcer

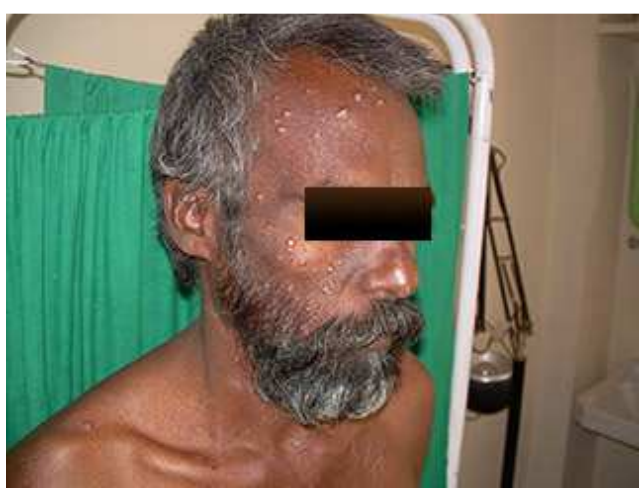

Extra genital molluscum contagiosum in HIV

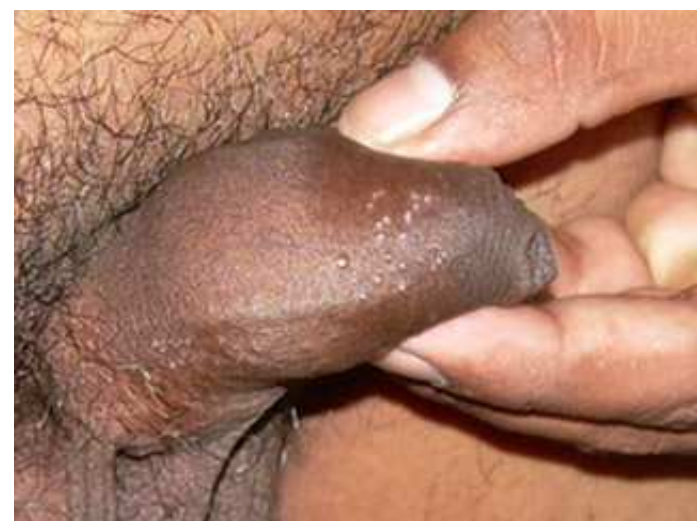

Molluscum contagiosum

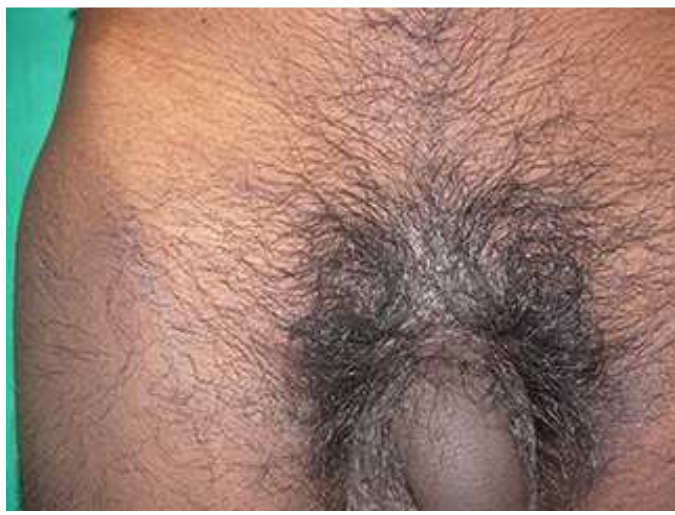

Pediculosis pubis 


\section{CASE STUDIES}

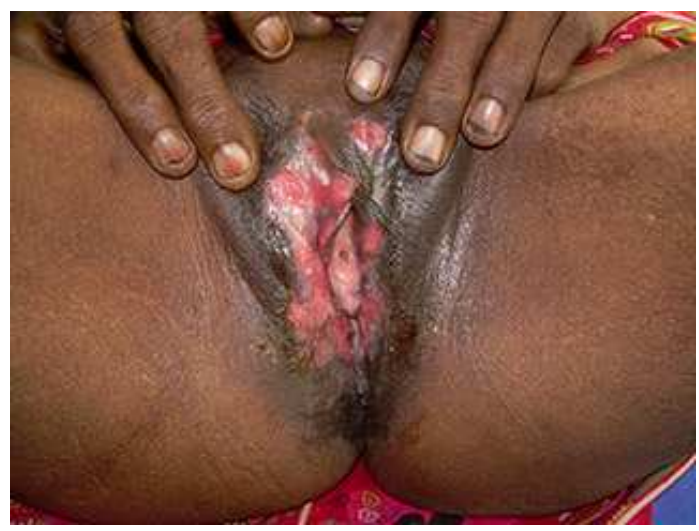

Recurrent, extensive genital herpes in a HIV positive female

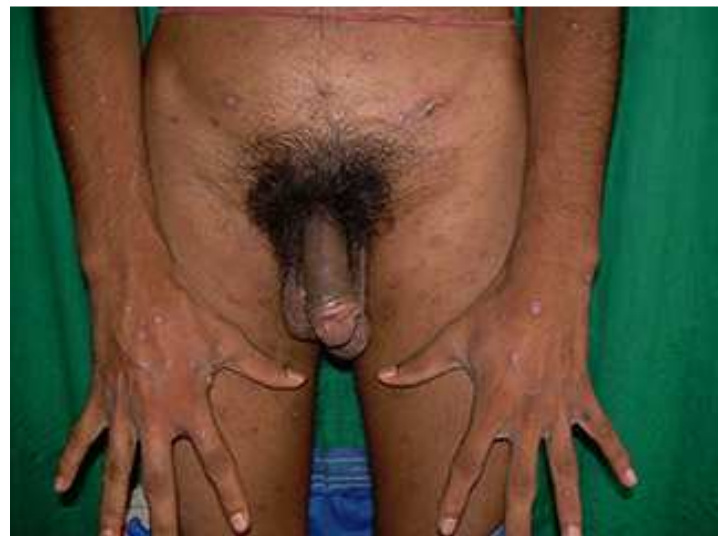

Scabies

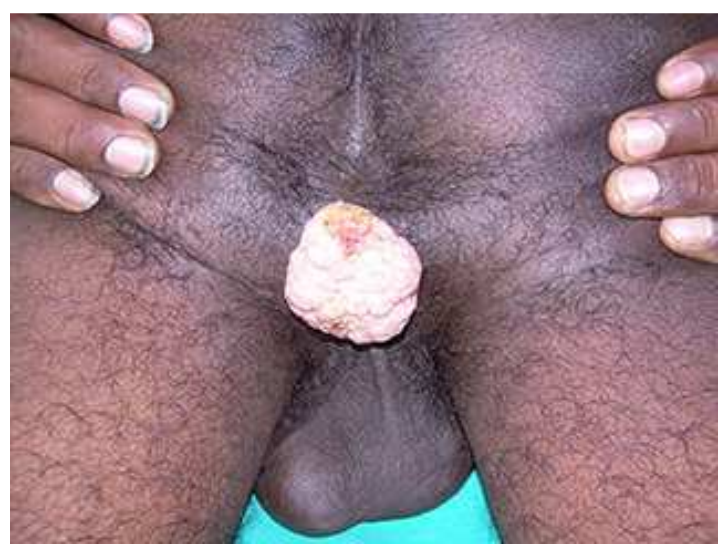

Wart in perineum in MSM

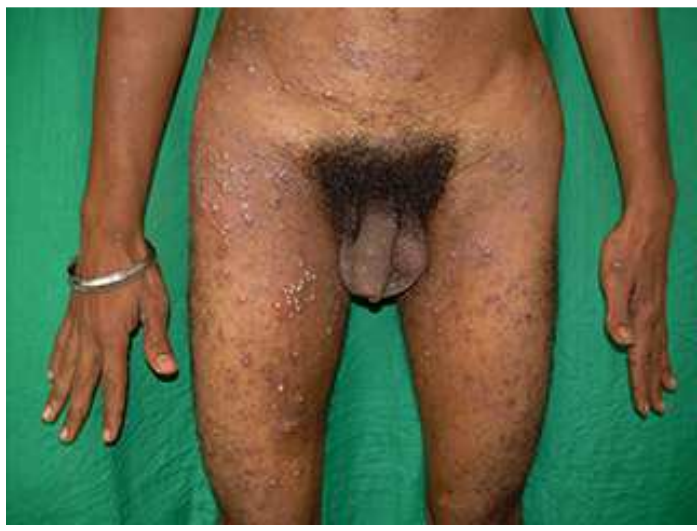

Scabies with secondary infection

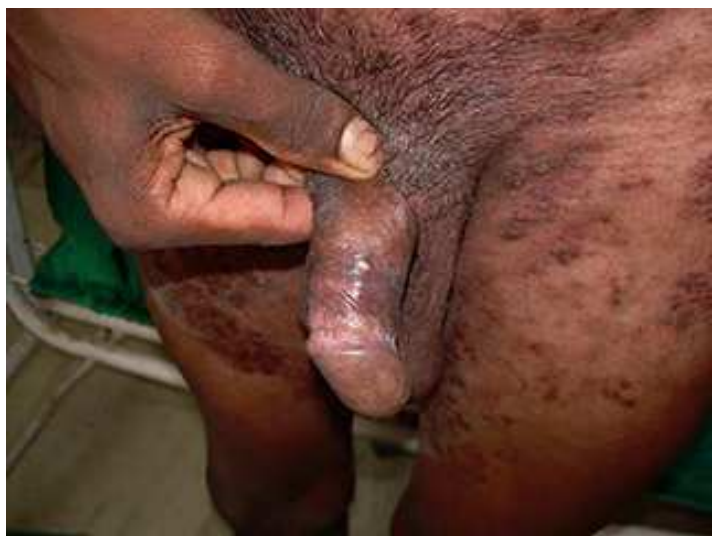

Tinea cruris with herpes genitalis in HIV 